\title{
Variability for seed size and yield in two tall dropseed populations
}

A. BOE

\section{Abstract}

Tall dropseed [Sporobolus asper (Michx.) Kunth var. asper] is a drought-tolerant, perennial, warm-season grass that has potential for forage and soil conservation purposes. A prairie and an adjacent roadside population from northeastern South Dakota were evaluated for seed yield and size characteristics for 3 years (1985-1987) in a space-plant nursery at Brookings, S.Dak. The objective was to obtain information on between and within population variability and intraplant variability that would provide a basis for designing a breeding program to improve seed production and quality in this germplasm. The roadside population produced significantly $(P<0.01)$ higher seed yields and larger mean 100-seed weight than the prairie population. Percent small seed (based on screen-separation of seed yields of individual plants into small, medium, and large seed size classes) decreased significantly $(P<0.01)$ as seed yield increased, but the volume of small seed increased concurrently with seed yield. Percent large seed increased significantly $(P<0.01)$ with increased seed yield and mean seed size. Highly significant $(P<0.01)$ differences were found among years for seed yield and mean seed size, but all plants produced seeds of each size class each year. Inter- and intrapopulation genetic variability was indicated for yield of the large seed size class. Screen-separation of individual plant seed yields could be used to identify superior genotypes to be used in the development of a cultivar that produces a high percentage of large seed.

Key Words: Sporobolus asper (Michx.) Kunth var. asper, seed production, population biology, native prairie

Tall dropseed [Sporobolus asper (Michx.) Kunth var. asper] is a tufted, perennial, warm-season grass that occurs throughout the prairie and grasslands of the central United States, along beaches of the New England Coast, in the cedar glades of Tennessee, and in the Ozark region of Missouri (Riggins 1977). It is a common associate of big bluestem (Andropogon gerardii Vitman), little bluestem [Schizachyrium scoparium (Michx.) Nash], Indiangrass [Sorghastrum nutans (L.) Nash], and sideoats grama [Bouteloua curtipendula (Michx.) Torr.] in the Great Plains (Vallentine 1967). Vegetational changes in True Prairie regions as a result of the drought of the 1930's indicated tall dropseed was a xeric grass that increased in abundance and cover (Robertson 1939, Weaver and Albertson 1943) and exhibited high seed set (Brown 1943) under severe drought conditions. Riggins (1977) found tall dropseed occurred most frequently along roadsides, railroad rights of way, and other disturbed areas.

Because of its ability to increase in abundance and produce fair to good forage for livestock (Johnson and Nichols 1982, Stubbendieck et al. 1982) in drought-stricken and other disturbed regions in native prairies, tall dropseed should be evaluated for possible genetic improvement. Poor seed quality and low seed production are commonly encountered in the evaluation and breeding of native grasses, thus the objective of this study was to assess varia-

\footnotetext{
Author is associate professor, Plant Science Department, South Dakota State University, Brookings 57007.

This article is a contribution from the South Dakota Agricultural Experiment Station Journal Series No. 2401.

Manuscript accepted 28 June 1989.
}

bility for seed size and yield in individuals from 2 populations of tall dropseed from different ecological situations (native grassland and the margin of a nearby unpaved road) in northeastern South Dakota. Information obtained will be useful for design of a breeding program aimed at improving seed yield and quality in this species.

\section{Materials and Methods}

The original seed collections were made in September 1980 from: (1) 20 random plants from a population of several hundred plants in native grassland (prairie) near Big Stone Lake in north eastern South Dakota, and (2) a colony of 3 plants at the edge of an unpaved road (roadside) approximately $0.5 \mathrm{~km}$ from the native stand. Panicles were hand-harvested and bulked by population. Seeds (the seed unit of tall dropseed is actually a utricle, but will henceforth be referred to as a seed) were separated from spikelet bracts by hand-threshing on a rubboard.

In February 1984, seeds of the 2 populations were planted in the greenhouse at a depth of $1.5 \mathrm{~cm}$ in $7.5-\mathrm{cm}$ diameter clay pots $(10-15$ seeds/pot). Four weeks after planting, plants were thinned to 1 vigorous seedling/pot. Thirty-five plants per population were transplanted in June 1984 to a space-plant (1 m inter-plant spacings) nursery on a Vienna loam, nearly level [fine-loamy, mixed Udic Haploborolls] soil near Brookings, S.Dak., in a randomized complete block design with 7 replications of 5 plants/population.

In September 1985, 1986, and 1987, all panicles of each plant were hand-harvested and threshed on a rubboard. Total seed yield and weights of 2 random 100-seed samples were obtained for each plant. Seed yields of individual plants in 1985 and 1986 were divided into 3 size classes by using screens with $24 \times 24$ and $26 \times 26$ openings per $6.25 \mathrm{~cm}^{2}$. Seeds that passed through both screens were considered small; those that only passed through the $24 \times 24$ were considered medium, and those that did not pass through either screen were considered large. The small seed size class was obtained for the 1987 individual plant seed yields by using the $26 \times$ 26 screen, but the remaining seed was not divided into medium and large classes. Weights of two 20-seed samples were determined for each of the 3 seed size classes for individual plants in 1985 and 1986.

Seed yield and weight data were subjected to analyses of variance for which populations and years were considered fixed and replications and plants within population $X$ replication units were considered random.

\section{Results and Discussion}

Seed yields fluctuated widely across years (Table 1). The 1986 mean seed yield was nearly 5 times greater than that of 1987 . The substantial reduction in 1987 accompanied severe decline in general vigor and reproductive culm production throughout the nursery. Tall dropseed is an autogamous, small-seeded, caespitose colonizer of disturbed areas (Weaver 1954) in native prairie regions, suggesting that it may be a short-lived perennial (Stebbins 1957). However, more information on persistence characteristics is needed before it can be determined if large sexual reproductive efforts, such as occurred in 1986, reduce vegetative and reproduc- 
Table 1. Mean annual seed yields and 100 -seed weights for 2 populations of tall dropseed grown in a space-plant nursery at Brookings, SD.

\begin{tabular}{lcc}
\hline \hline Year & Seed yield & 100-Seed weight \\
\hline & $-\mathrm{g}-$ & $-\mathrm{mg}-$ \\
1985 & 8.4 & 61.6 \\
1986 & 17.8 & 63.6 \\
1987 & 3.8 & 54.0 \\
LSD $(0.05)$ & 2.4 & 1.9 \\
\hline
\end{tabular}

tive vigor in the subsequent growing season, as has been reported for the short-lived perennial Poa annua L. (Law 1979).

The roadside population produced significantly $(P<0.01)$ higher seed yields and greater yields of the large seed size class than the prairie population (Table 2). Significant $(P<0.05)$ differences were

Table 2. Mean yield and contribution to total yield of 3 size classes obtained by screening seeds of individual plants of 2 populations of tall dropseed from northeastern South Dakota grown in a space-plant nursery at Brookings, SD in 1985-87.

\begin{tabular}{|c|c|c|c|c|c|c|}
\hline \multirow{3}{*}{$\begin{array}{l}\text { Main } \\
\text { effect }\end{array}$} & \multicolumn{6}{|c|}{ Seed classes obtained by screening } \\
\hline & \multicolumn{3}{|c|}{ Class yield } & \multicolumn{3}{|c|}{ Contribution to total yield } \\
\hline & Small & Medium & Large & Small & Medium & Large \\
\hline & -- & . & $-\ldots$ & 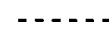 & $--\%$ & $-\cdots$ \\
\hline $\begin{array}{l}\text { Year } \\
1985 \\
1986 \\
1987\end{array}$ & $\begin{array}{l}1.35^{*} \\
2.21 \\
0.95\end{array}$ & $\begin{array}{l}2.21^{* *} \\
4.50 \\
-1\end{array}$ & $\begin{array}{c}4.52^{* *} \\
10.64 \\
--\end{array}$ & $\begin{array}{l}19.2 * * \\
13.2 \\
25.0\end{array}$ & $\begin{array}{r}27.9 \\
26.5 \\
-\end{array}$ & $\begin{array}{l}52.9^{*} \\
59.9 \\
-\end{array}$ \\
\hline $\begin{array}{c}\text { Population } \\
\text { Prairie } \\
\text { Roadside }\end{array}$ & $\begin{array}{l}1.88 \\
1.67\end{array}$ & $\begin{array}{l}3.17 \\
3.54\end{array}$ & $\begin{array}{l}4.99 * * \\
10.17\end{array}$ & $\begin{array}{l}20.66^{* *} \\
11.68\end{array}$ & $\begin{array}{l}31.03^{* *} \\
23.37\end{array}$ & $\begin{array}{l}48.30^{* *} \\
64.57\end{array}$ \\
\hline
\end{tabular}

*;**Annual or population means in same seed class columns significantly different at the 0.05 and 0.01 levels, respectively.

Data not obtained.

also found among plants within the 5-plant population $X$ replication units for yield of the large seed size class. The roadside population outyielded the prairie population by 64,47 , and $14 \%$ in 1985 , 1986 , and 1987, respectively. Overall mean seed yields were $11.9 \pm$ 0.6 and $8.1 \pm 0.6 \mathrm{~g} /$ plant for roadside and prairie populations, respectively. The large decrease in relative difference between populations in 1987 was associated with the aforementioned decline in overall mean seed yields and plant vigor.

Highly significant differences were found among years for mean 100 -seed weight (Table 1). Associated with the 79\% reduction seed yield in 1987 was a $15 \%$ decrease in mean seed size. Considerably fewer seeds were produced per plant in 1987 than in 1985 and 1986, and their mean 100-seed weight was significantly lighter.

The roadside population had a significantly $(P<0.01)$ greater mean 100-seed weight than the prairie population. Grand 100 -seed weight means were 56.8 and $62.4 \mathrm{mg}$ for prairie and roadside populations, respectively. Although only 35 plants of each population were evaluated in the nursery, the consistent superiority of the roadside population for seed yield and size over the 3-year study indicates genetic variability between the populations for these traits. The roadside colony may well have originated from the nearby prairie, but a more distant seed source is also conceivable. Without knowing the source, it is impossible to determine if the population differences observed resulted from selection forces related to microenvironmental differences between the prairie and roadside sites. Nevertheless, dissimilarities between populations of tall dropseed within small geographical areas were also reported by Riggins (1977). For example, her biosystematic study of the tall dropseed complex revealed that 2 Webster Co., Iowa, populations, one from remnant prairie and the other from a roadside approximately 500 meters away, were distinctly dissimilar based on cluster analyses of 29 morphological variables, while 2 Mississippi populations approximately 60 miles apart were highly similar. This same phenomenom has been observed in genetic variability studies of autogamous annual colonizing species. Populations of predominantly self-pollinated species are often comprised of many different homozygous genotypes (Imam and Allard 1965, Kannenberg and Allard 1967), and contain as much total genetic variability as populations of outcrossing species (Allard 1965). Allard (1965) reported morphological differences between populations of wild oat (Avena fatua L.) that occurred very short distances apart were related to abrupt changes in ecological circumstances, such as topography or edaphic factors. The distance separating the 2 populations in this study was less than $1 \mathrm{~km}$, but the ecological situations were quite different. The prairie population was comprised of several hundred scattered individuals growing on a north-facing slope dominated by other perennial warm-season, native grasses. The roadside population consisted of 3 clumped individuals growing on an unpaved roadside that was being predominantly colonized by annual weedy species common to the region. In this study, sampling microenvironments within a small geographic area identified variability that may be of value for genetic improvement of seed production and quality in this northeastern South Dakota germplasm.

Significantly higher yields were obtained for all 3 seed size classes in 1986 than in 1985 (Table 2). Percent small seed decreased as seed yield increased, but the volume of small seed produced per plant actually increased. In 1987 , the poorest seed production year, the small seed size class comprised $25.0 \%$ of the total seed yield. The larger allocation to seed production in 1986 included greater numbers of seeds in all 3 size classes and a significant increase in percent large seed (Table 2). Mean 20-seed weight of the roadside population was approximately $7 \%$ greater than that of the prairie population for the large seed class, but mean differences of less than $1 \%$ were found between populations for medium and small seed classes (Table 3).

Table 3. Mean 20-seed weights of 3 seed size classes from 2 populations of tall dropseed from northeastern South Dakota grown in a space-plant nursery at Brookings, SD in 1985-87.

\begin{tabular}{|c|c|c|c|}
\hline \multirow[b]{2}{*}{ Population } & \multicolumn{3}{|c|}{ Seed size class } \\
\hline & Large & Medium & Small \\
\hline & $\ldots$ & $--\mathbf{m g}--$ & $\cdots-\cdots$ \\
\hline Prairie & $13.72 * *$ & $11.27 \mathrm{NS}$ & $8.73 \mathrm{NS}$ \\
\hline Roadside & 14.75 & 11.37 & 8.72 \\
\hline $\mathrm{SE}^{1}$ & 0.20 & 0.10 & 0.13 \\
\hline
\end{tabular}

**, NS Population means in same column significant at the 0.01 level and not significantly different, respectively.

'Standard error of difference between population means.

Results of this study revealed that plants of tall dropseed did not differ in mean seed size by producing uniform-sized seeds of different masses. All 70 plants produced seeds of the 3 size classes. Variations in mean 100-seed weight between populations and among plants within populations depended to a great extent on variations in proportions of seeds of different size classes (Table 2). Absolute increases or decreases in individual seed size probably had little influence on mean 100-seed weight, even though analyses of variance indicated a highly significant $(P<0.01)$ difference between populations and a significant $(P<0.05)$ plants in population $X$ replications units mean square for mean 20-seed weight of the large seed class. Since genetic variability for seed yield, mean 100 -seed size, and yield of the large seed size class was indicated, 
improvement for these characteristics in this germplasm could be simply approached by screen-separating seeds of individual plants and selecting those that consistently produce the largest yields of seeds above a critical size. The critical size could be determined from seedling vigor studies in the greenhouse and field. Knipe (1970) screen-separated 6 seed lots of alkali sacaton (Sporobolus airoides Torr.) into 6 size classes and found seedlings from large seed grew faster and were better adapted to establishment in harsh areas than those from small seed. He suggested the success of field seedlings would be enhanced if operations were restricted to use of large seeds. Since the goal of the improvement program would be to increase yield of seeds larger than the previously determined critical size, screening would provide a quick and accurate method for identifying superior genotypes. This method may also be applicable to other autogamous range grass species that produce freeflowing seed units that can be accurately separated into size classes by screening.

\section{Literature Cited}

Allard, R.A. 1965. Genetic systems associated with colonizing ability in predominantly self-pollinated species. In: H.G. Baker and G. L. Stebbins (eds.) The genetics of colonizing species. Academic Press, N.Y.

Brown, H.R. 1943. Growth and seed yields of native prairie plants in various habitats of the mixed prairie. Trans. Kans. Acad. Sci. 46:87-99.
Iman, A.G., and R.W. Allard. 1965. Population studies in predominantly self-pollinated species. VI. Genetic variability between and within natural populations of wild oats from differing habitats in California. Genetics 51:49-62.

Johnson, J.R., and J.T. Nichols. 1982. Plants of South Dakota grasslands. S. Dak. Agr. Exp. Sta. Bull 566 (Rev. Ed.).

Knipe, O.D. 1970. Large seeds produce more, better alkali sacaton plants. J. Range Manage. 23:369-371.

Kannenberg, L.W., and R.W. Allard. 1967. Population studies in predominantly self-pollinated species. VIII. Genetic variability in the Festuca microstachys complex. Evolution 21:227-240.

Law, R. 1979. The cost of reproduction in annual meadow grass. Amer. Natur. 113:3-16.

Riggins, R. 1977. A biosystematic study of the Sporobolus asper complex (Gramineae). Iowa State J. Res. 51:287-321.

Robertson, J.H. 1939. A quantitative study of true-prairie vegetation after three years of extreme drought. Ecol. Mono. 9:431-491.

Stebbins, G.L., Jr. 1957. Self-fertilization and population variability in the higher plants. Amer. Natur. 91:337-354.

Stubbendieck, J., S.L. Hatch, and K.J. Kjar. 1982. North American range plants. Univ. Nebraska Press. Lincoln.

Vallentine, J.F. 1967. Nebraska range and pasture grasses. Univ. Nebraska Ext. Circ. 67-170.

Weaver, J.E. 1954. North American prairie. Johnsen Pub. Co. Lincoln, Neb.

Weaver, J.E., and F.W. Albertson. 1943. Resurvey of grasses, forbs, and underground plant parts at the end of the great drought. Ecol. Mono. 13:65-117.

\title{
Call for Papers \\ IVth INTERNATIONAL RANGELAND CONGRESS
}

\author{
22-26 April 1991 \\ Montpellier, France
}

The IVth INTERNATIONAL RANGELAND CONGRESS will convene in MONTPELLIER (FRANCE), under the aegis of AGROPOLIS (International Complex for Research and Higher Education) and the ASSOCIATION FRANÇAISE de PASTORALISME (AFP-French Association for Range Management).

The official languages of the IVth IRC will be French and English; permanent simultaneous translation will be available, including during field trips.

The Scientific Committee wishes to emphasize issues related to the mediterranean and subtropical isoclimatic zones, but other subjects will be addressed. In particular, general issues of methodologies and management techniques and problems pertaining to other ecoclimatic zones are envisaged.

Registration fees are 2500 FF (approx. 400 US\$) before Oct. 31, 1990 for full members and 1500 FF (approx. 250 US\$) for associate members.

Deadlines for contributions are as follows:

* Title and 50-100 words synopsis : March 31, 1990

* 300-word summary and

* Full paper (4 pages of Journal of Range Management, i.e. approx 4000 words): July 31, 1990

For further information on the IVth IRC, please contact:

Dr. H.N. Le Houérou, Chairman

IVth INTERNATIONAL RANGELAND CONGRESS

C.N.E.A.R.C.

PO Box 5098

F-34033 MONTPELLIER Cedex

France

Telex: 490549 F; $\quad$ Fax: (33) 67410232 